\title{
92. Note on a Larva of Gipsy Moth with Pupal Antennae.
}

By Kiyoshi TakewakI.

Zoological Institute, Faculty of Science, Tokyo Imperial University.

(Rec. June 9, 1928. Comm. by A. OKA, M.I.A., June 12, 1928.)

Among the fixed material of the last instar larvae of the gipsy moth, Limantria dispar var. japonica, I happened to come across, in the summer of 1927, a specimen with antennae of singular shape.

The normal antenna of the larva at the same stage measures 1-1.2 mm. in length and, as is shown in Fig. 1, is three jointed with a styloconic sensilla, two trichoid sensillae and a few basiconic sensillae at its distal end.

Fig. 2 shows the head with enlarged antennae in front view. The specimen, it may be stated, is somewhat smaller than ordinary ones (30-30 $\mathrm{mm}$.), the body length being about $27 \mathrm{~mm}$. Both the right and left abnormal antennae are very similar in shape, each measuring $2.2 \mathrm{~mm}$. in length. They are destitute of joints. Neither are any sensillae present on them. The antenna is spindle shaped with a short stalk. It is of a light yellow color in alcohol after the fixation with Bouin's fluid. I do not know how it looked when alive.

These malformed antennae $(2.2 \mathrm{~mm}$.) are much smaller than those of the pupal stage (6.5-7 mm.), it is true, but they resemble each other very strikingly. That they not only show similarity in external appearance but in internal structure as well, is revealed by the comparison of sections.

Fig. 3 represents a section through the left abnormal larval antenna, and Fig. 4 that through a pupal antenna. In both of them one sees a single layer of elongated hypodermal cells beneath the cuticle (Fig. 5). Within is a cavity enclosed by the basement membrance. In the cavity are found fine branches of trachea and nerves. Leucocytes are present in the outside as well as in the inside of the basement membrance.

For comparison a section through a normal larval antenna is shown in Fig. 6. In this one can readily see that all the hypodermal cells are cuboidal in strong constrast with those of the pupa.

It is interesting to note that, though the abnormal antenna is free all around except the basal part of the stalk for attachement, the cuticle is thinner along the posterior surface, that is, along the longest side of the triangular outline of the section, as in shown in Fig. 3. This 
thickening is also present in the pupal antenna; the cuticle is much thicker on the outer surface (the right-hand side of Fig. 4) and is thin on the side apposed to the body (the left-hand side of the same figure).

From the above observations I do not hesitate to conclude that the abnormal antennae of the gipsy moth under consideration are in reality pupal antennae precoceously developed in the larval stage. This is undoubtedly a case of prothetely, an interesting phenomenon so designated for the first time by Kolbe (1903). Lindner described in 1915 an example of prothetely, in which a larva had pupal antennae as in the present case but his paper is unfortunately not accessible to me.

\section{Literature.}

Kolbe, J. 1902 Über vorschnelle Entwicklung von Puppen und Imagoorganen bei Raupen von Lepidopteren (Dendrolimus pini L.). Sitzber. Ges. nat. Freunde Berlin.

1903 Über verschnelle Entwicklung (Prothetelie) von Puppen und Imagoorganen bei Lepidopteren und Coleopterenlarven nebst Beschreibung einer abnormen Raupe des Kieferspinners, Dendrolimus pini L. Allgem. Zeitsch. für Entomologie. Bd. 8.

Lindner, E. 1915 Eine Raupe mit Puppenantennen. Zeitsch. wiss. Insektenbiologie. Bd. 11 .

\section{Explanation of Figures.}

Fig. 1 Front view of head of last instar larva. $\times 6.5$

Fig. 2 Front view of larva with prothetelic antennae. $\times 10$

Fig. 3 Cross section of prothetelic antenna. $\times 60$

Fig. 4 Cross section of normal pupal antenna. $\times 60$

Fig. 5 A portion of cross section of prothetelic antenna. $\times 250$

Fig. 6 Cross section of first joint of antenna of last instar larva. $\times 250$

b basement membrane.

1 leucocyte.

c cuticle.

$n$ nerve.

h hypodermal cell.

$\mathrm{t}$ trachea. 

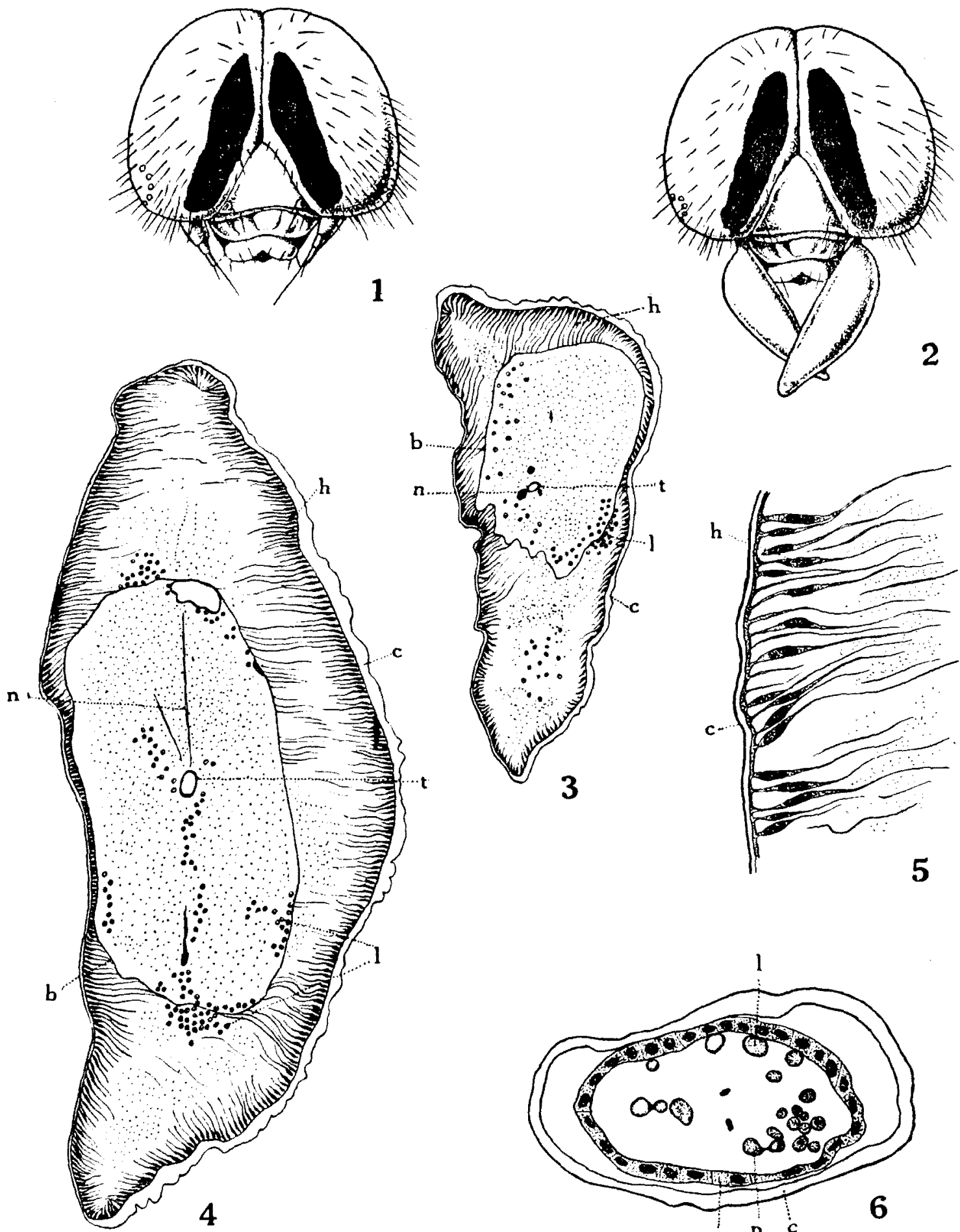